\title{
FACTOR STRUCTURE AND PSYCHOMETRIC PROPERTIES OF THE CROATIAN SHORT VERSION OF THE EMPATHY QUOTIENT
}

\author{
Anja Wertag \\ Institute of Social Sciences Ivo Pilar \\ Marulićev trg 19/I, 10000 Zagreb \\ Anja.Wertag@pilar.hr \\ Ivana Hanzec \\ Psychology Department, Centre for Croatian Studies, University of Zagreb \\ Borongajska cesta 83d, 10000 Zagreb \\ ihanzec@hrstud.hr
}

\begin{abstract}
The Empathy Quotient (EQ, Baron-Cohen \& Wheelwright, 2004) measures empathy as an ability to identify what someone else is thinking and feeling, and to respond to their thoughts and feelings with an appropriate emotion. Although the questionnaire was developed in order to be sensitive to empathy deficits as a part of psychopathology, it is often used in other areas of psychological research as well. Therefore, the aim of this study was to determine the factor structure and psychometric properties of the short version of the translated Empathy Quotient (EQ-28) that has psychometric superiority over the original version (Lawrence et al., 2004). Data was collected on-line on a convenient sample $(N=115 ; 81$ female and 34 male) with a mean age of $31.30(S D=7.49)$, within a larger study. The results of the principal component analysis showed a clear three-factor solution consistent with the structure proposed by Lawrence et al. (2004). Cronbach's alpha coefficients indicated high internal consistency of the Cognitive Empathy and the Emotional Reactivity subscales, unlike the Social Skills subscale. The correlations of the EQ-28 subscales and the relevant subscales of the Interpersonal Reactivity Index (Davis, 1983) provided information about the convergent validity of the Cognitive Empathy and the Emotional Reactivity subscales, while the correlations with measures of altruism (measured by HEXACOPI-R, Lee \& Ashton, 2004) and the Dark Triad (Jones \& Paulhus, 2014) showed the theoretically expected relationships between the given constructs. On the basis of the results of this preliminary study it can be concluded that the Croatian version of the EQ-28 has satisfactory metric characteristics and represents a good measure of cognitive and affective empathy, but these results should be replicated on a larger and more gender balanced sample.
\end{abstract}

Key words: Empathy Quotient, psychometric properties, Croatian version 


\section{INTRODUCTION}

Empathy, in the most general sense, refers to the ability to understand and share the feelings of others, and is an essential part of our social functioning. Given the importance of empathy for social functioning, it is not surprising that researchers from the fields of social and developmental psychology as well as evolutionary psychology have great interest in this construct. Despite its importance, there have been dissents in the definitions of empathy. Although traditional researchers have usually viewed empathy either in terms of affect (e.g. Mehrabian \& Epstein, 1972), or have taken a more cognitive approach (e.g. Hogan, 1969), lately researchers generally agree that empathy has both an emotional and a cognitive component (e.g. Raboteg-Šarić, 1995; Singer, 2006; Baron-Cohen, 2011), which has been confirmed in neuropsychological research (Shamay-Tsoory, Ahoron-Peretz \& Perry, 2009).

In the area of recent empathy research, the work of the British psychologist Simon Baron-Cohen, who dedicated more than 20 years to this field with his team at The Cambridge Autism Research Centre, is especially prominent. One of the results of this comprehensive research is the Empathy Quotient instrument (EQ, Baron-Cohen \& Wheelwright, 2004) that measures empathy as the ability to recognize and understand the thoughts and feelings of others, as well as to respond to others' thoughts and feelings with appropriate emotion. Although the EQ was designed to measure the lack of empathy as a feature of psychopathology, it is now often used in other areas of psychological research as well. The original scale consists of 60 items ( 40 of them measure empathy and 20 filler items serve to distract the participants from focusing on empathy), but Lawrence et al. (2004) suggested shortening the scale to 28 items loading on three factors: Cognitive Empathy (CE; 11 items), Emotional Reactivity (ER; 11 items) and Social Skills (SS; 6 items). This three-factor structure of the EQ has been partly confirmed in translated versions of the EQ in Japan (Wakabayashi et al., 2007), France (Berthoz et al., 2008), Canada (Lepage et al., 2009), Korea (Kim \& Lee, 2010), Italy (Preti et al., 2011), Serbia (Dimitrijević et al., 2012) and Netherlands (Groen et al., 2015) and the scale has proven to be a valid and reliable tool for assessing empathy in both clinical and non-clinical samples.

To the best of our knowledge, this instrument has not yet been used in Croatia; therefore the aim of this study was to determine the factor structure and psychometric properties of the Croatian translation of the short version of the EQ (EQ28; Lawrence et al., 2004). Across international studies, the EQ has been validated by means of the correlations between the EQ and other measures of empathy or measures related to emotional functioning, and by demonstrating typical gender differences (i.e. female superiority in empathizing). For that reason, we examined the relationship of the EQ-28 with another empathy measure, the Interpersonal Reactivity Index (IRI, Davis, 1983), which incorporates both the emotional and the cognitive component of empathy and is the most prominent empathy measure. 
Furthermore, we included measures of altruism, which is linked positively with empathy (according to the empathy-altruism hypothesis; Batson, 1991), and the Dark Triad, a constellation of three overlapping personality traits: Machiavellianism, narcissism and psychopathy, which share a common core of callousness (i.e. low empathy; Jones \& Paulhus, 2011; Jones \& Figuredo, 2013). Given the substantial theoretical overlap between empathy and these constructs, we expected at least medium-sized correlations between them (positive in the case of altruism and negative in the case of the Dark Triad). Finally, in line with all previously mentioned EQ studies, we expected to find gender differences (i.e. more pronounced empathy in females) on the EQ-28.

\section{METHOD}

\section{Participants and procedure}

Data was collected from 115 participants in Croatia ( 81 female and 34 male), within a larger on-line study that lasted one month. Although participants were invited to participate in the study via social networks, mailing lists and web-pages of selected universities and faculties, the sample for this study consisted only of participants who indicated they were something other than students $(70.4 \%$ indicated they were employed, $18.3 \%$ unemployed). Participants' age range was from 18 to 54 years, with an average age of $31.30(S D=7.49)$.

\section{Instruments}

The short version of the Empathy Quotient (EQ-28, Lawrence et al., 2004; Krat$k$ a verzija Kvocijenta empatije*) was translated into the Croatian language independently by two psychologists, and all discrepancies were resolved by a consensus among the translators. After a back translation procedure, several minor inconsistencies were amended through a discussion between the translators and the backtranslator. The scale consists of 28 items on which participants indicate their level of agreement on a 4-point scale (1 - strongly agree, 4 - strongly disagree). The items are scored 0,1 or 2 , with participants receiving mark 0 for a non-empathic response and mark 1 or 2 depending on the strength of an empathic response.

* Both original and Croatian versions of the EQ together with scoring key are available for download from the Autism Research Center webpage

https://www.autismresearchcentre.com/arc_tests 
Interpersonal Reactivity Index (IRI, Davis, 1983) - 5 items from the Perspective Taking subscale (cognitive empathy, $\alpha=.546$ ) and 4 items from the Emphatic Concern subscale (emotional empathy, $\alpha=.688$ ). On these and two following scales the participants indicate their level of agreement with each item on a 5-point scale (1 - strongly disagree, 5 - strongly agree).

The HEXACO-PI-R (Lee \& Ashton, 2004) - The Altruism (versus Antagonism) scale (4 items, $\alpha=.585$ ) assesses a tendency to be sympathetic and soft-hearted toward others.

Short Dark Triad (SD3, Jones \& Paulhus, 2014) - 28 items that measure three dark traits ( 9 items per trait): Machiavellianism $(\alpha=.771)$, narcissism $(\alpha=.736)$ and psychopathy $(\alpha=.694)$.

\section{RESULTS}

The adequacy of the correlation matrix for factorization was tested by Bartlett's Test of Sphericity $\left(\chi^{2}(387)=1421.44, p<.001\right)$, as well as with the Kaiser-MeyerOlkin Measure of Sampling Adequacy $(\mathrm{KMO}=.792)$. Following the procedures of other EQ validation studies (i.e. Dimitrijević et al., 2012; Lawrence et al., 2004), we conducted a principal component analysis (PCA) with Varimax rotation and Kaiser Normalization, which converged in 6 iterations and yielded interpretable three-factor solution presented in Table 1. Extracted factors accounted for $44.53 \%$ of the variance. The vast majority of item loadings corresponded well with the factor solution proposed by Lawrence et al. (2004). The exceptions were item EQ22 that had higher loading on CE factor (.689) than the supposed ER (-.268), three

Table 1. Rotated component matrix with factor loadings on three components of the EQ28 (Varimax rotation with Kaiser Normalization)

\begin{tabular}{lccc}
\hline No. of the original EQ item & $\begin{array}{c}\text { Cognitive } \\
\text { Empathy }\end{array}$ & $\begin{array}{l}\text { Emotional } \\
\text { Reactivity }\end{array}$ & $\begin{array}{c}\text { Social } \\
\text { Skills }\end{array}$ \\
\hline EQ25 & $\mathbf{. 8 1 2}$ & & \\
EQ26 & $\mathbf{. 7 4 1}$ & -.381 & \\
EQ41 & $\mathbf{. 7 3 2}$ & & \\
EQ22 & .689 & $\mathbf{- . 2 6 8}$ & \\
EQ19 & $\mathbf{. 6 6 5}$ & & \\
EQ52 & $\mathbf{. 6 5 1}$ & & \\
EQ58 & $\mathbf{. 6 4 4}$ & & .327 \\
EQ55 & $\mathbf{. 5 8 9}$ & & \\
EQ1 & $\mathbf{. 5 8 8}$ & -.369 & \\
EQ14 & $\mathbf{- . 5 8 0}$ & & .457 \\
EQ54 & $\mathbf{. 5 6 6}$ & &
\end{tabular}




\begin{tabular}{lccc}
\hline & & & \\
\hline No. of the original EQ item & $\begin{array}{c}\text { Cognitive } \\
\text { Empathy }\end{array}$ & $\begin{array}{l}\text { Emotional } \\
\text { Reactivity }\end{array}$ & $\begin{array}{c}\text { Social } \\
\text { Skills }\end{array}$ \\
\hline EQ44 & $\mathbf{. 5 3 0}$ & & .568 \\
EQ36 & $\mathbf{. 4 4 3}$ & & \\
EQ43 & .483 & $\mathbf{- . 2 8 0}$ & \\
EQ27 & & $\mathbf{. 7 5 5}$ & \\
EQ50 & & $\mathbf{. 7 2 3}$ & \\
EQ48 & & $\mathbf{. 7 1 0}$ & \\
EQ32 & & $\mathbf{. 6 5 2}$ & \\
EQ21 & & $\mathbf{. 5 8 2}$ & \\
EQ29 & & $\mathbf{. 4 7 5}$ & \\
EQ42 & .391 & $\mathbf{- . 4 7 5}$ & $\mathbf{4 1 1}$ \\
EQ59 & .377 & $\mathbf{- . 1 9 9}$ & .330 \\
EQ6 & .276 & $\mathbf{- . 1 8 6}$ & $\mathbf{- . 6 8 2}$ \\
EQ12 & & & $\mathbf{- . 6 8 2}$ \\
EQ8 & & & $\mathbf{. 4 6 0}$ \\
EQ35 & & & $\mathbf{- . 3 6 8}$ \\
EQ57 & & & \\
EQ4 & & & \\
\hline
\end{tabular}

Note. In bold are loadings on the supposed factors. The EQ is available for download from the Autism Research Center webpage https://www.autismresearchcentre.com/arc_tests

items that should have loadings on ER had higher loadings on CE (item EQ43) or both CE and SS (items EQ59 and EQ6), item EQ14 that didn't have a loading on the supposed SS factor and item EQ4 that should load on SS factor didn't load on any of the three factors.

Although the solution based on PCA would better fit the data in this sample, we decided to keep the original solution proposed by Lawrence et al. (2004) in order to preserve compatibility with other translations and studies.

Table 2. Mean, standard deviation and reliability of the EQ-28 subscales

\begin{tabular}{|c|c|c|c|c|c|c|c|c|}
\hline & \multicolumn{2}{|c|}{ Male } & \multicolumn{2}{|c|}{ Female } & \multicolumn{2}{|c|}{ Total } & \multirow[b]{2}{*}{$t(113)$} & \multirow[b]{2}{*}{$\alpha$} \\
\hline & $M$ & $S D$ & $M$ & $S D$ & $M$ & $S D$ & & \\
\hline Cognitive Empathy & 10.53 & 4.22 & 11.69 & 5.10 & 11.35 & 4.87 & 1.263 & .892 \\
\hline Emotional Reactivity & 9.09 & 4.13 & 12.22 & 4.41 & 11.30 & 4.55 & $3.638 * *$ & .812 \\
\hline Social Skills & 5.91 & 1.93 & 5.63 & 2.12 & 5.71 & 2.06 & -.695 & .397 \\
\hline Empathy Quotient & 25.53 & 8.79 & 29.54 & 9.40 & 28.36 & 9.37 & $2.188^{*}$ & .871 \\
\hline
\end{tabular}

Note. $N_{\text {Male }}=34, N_{\text {Female }}=81 ; * p<.05, * * p<.01$ 
Table 3. Intercorrelations of the EQ-28 and its subscales with other variables

\begin{tabular}{lccccccccc}
\hline & EQ-28 & CE & ER & SS & PT & EC & M & N & P \\
\hline CE & $.893^{* *}$ & & & & & & & & \\
ER & $.840^{* *}$ & $.568^{* *}$ & & & & & & & \\
SS & $.584^{* *}$ & $.446^{* *}$ & $.272^{* *}$ & & & & & & \\
PT & $.475^{* *}$ & $.366^{* *}$ & $.437^{* *}$ & $.332^{* *}$ & & & & & \\
EC & $.573^{* *}$ & $.400^{* *}$ & $.676^{* *}$ & .168 & $.411^{* *}$ & & & & \\
M & -.155 & -.030 & $-.225^{*}$ & -.137 & $-.372^{* *}$ & $-.387^{* *}$ & & & \\
N & .000 & .049 & -.074 & .050 & $-.216^{*}$ & -.108 & $.276^{* *}$ & & \\
P & $-.410^{* *}$ & $-.285^{* *}$ & $-.437^{* *}$ & $-.228^{*}$ & $-.477^{* *}$ & $-.525^{* *}$ & $.554^{* *}$ & $.278^{* *}$ & \\
Altruism & $.457^{* *}$ & $.306^{* *}$ & $.508^{* *}$ & $.231^{*}$ & $.351^{* *}$ & $.602^{* *}$ & $-.364^{* *}$ & $-.199^{*}$ & $-.565^{* *}$ \\
\hline
\end{tabular}

Note. $N=115 . \mathrm{EQ}=$ Empathy Quotient, $\mathrm{CE}=$ Cognitive Empathy, $\mathrm{ER}=$ Emotional Reactivity, $\mathrm{SS}=$ Social Skills, $\mathrm{PT}=$ Perspective Taking, $\mathrm{EC}=$ Empathic Concern, $\mathrm{M}=$ Machiavellianism, $\mathrm{N}=$ Narcissism, $\mathrm{P}=$ Psychopathy.

$* p<.05, * * p<.01$

As noted in Table 2, Cronbach's alpha coefficients showed high internal consistency of the EQ-28 as well as the CE and ER subscales, while the internal consistency of the SS subscale was low. Moreover, the SS had a lower correlation with the whole scale than the other two subscales (Table 3).

Gender differences in the EQ-28 scores followed the trend observed in other studies and in larger samples: females having higher scores on ER $\left(M_{\text {Female }}=12.22\right.$, $\left.M_{\text {Male }}=9.09, t=3.638, p<.01\right)$ and the total score $\left(M_{\text {Female }}=29.54, M_{\text {Male }}=25.53\right.$, $t=3.638, p<.01$ ), while there were no differences on other subscales (Table 2).

The EQ-28 subscales had positive intercorrelations ranging from .272 between ER and SS to .568 between CE and ER. The correlations between the EQ-28 and the two IRI subscales ranged from low to moderate: the lowest was between SS and PT (.332) and the highest between ER and EC (.676). Finally, the correlations of the EQ-28 subscales with altruism were moderate and positive (ranging from .306 for CE to .508 for ER) while the correlations with the Dark Triad were low to moderate and negative (ranging from -.225 for ER and Machiavellianism to - .437 for ER and psychopathy).

\section{DISCUSSION}

The aim of this study was to examine the basic psychometric properties of the short version of the Croatian translation of the Empathy Quotient (EQ-28; Lawrence et al., 2004). The principal component analysis yielded an interpretable three-factor solution that corresponds to the one in previous studies (Dimitrijević et al., 2012; 
Lawrence et al., 2004). Several items had loadings on more than one factor, and it is interesting to note that these items had cross-loadings in other studies with other samples as well, such as students (Dimitrijević et al., 2012; Muncer \& Ling, 2006) and clinical or non-clinical adult samples (Lawrence et al., 2004).

The reliability of the EQ-28 measured by Cronbach's alpha indicated high internal consistency of the overall result as well as the CE and the ER subscales. However, the reliability of the SS subscale was very low, similar to the finding in the Serbian sample $(\alpha=.320$, Dimitrijević et. al., 2012). The SS subscale was the least reliable subscale in other studies as well (Groen et al., 2015; Kim \& Lee, 2010; Muncer \& Ling, 2006). This could be due, to a certain extent, to the low number of SS items, but also to the fact that the scale predominantly consists of reversed items, which were shown to have overall lower consistency than forward items (Groen et al., 2015). Lower intercorrelations of the SS scale with other variables could be due to the lower reliability of this scale, but they could also suggest that social skills should be investigated as a concept related to empathy, and not its subset.

In line with previously documented female superiority in empathy (Baron-Cohen \& Wheelwright, 2004; Davis, 1983; Muncer \& Ling, 2006), the results of this study show that the largest gender differences were on ER and EQ-28, while there were no gender differences on SS and CE. Gender differences in the emotional components of empathy are consistent with evolutionary perspective, as females should be more sensitive to the offspring's needs, as well as warm and caring.

The correlations between the EQ-28 subscales and IRI (Davis, 1983) are moderate and significant, and provide information about convergent validity of the $\mathrm{CE}$ and the ER subscales. Our results showing generally higher correlations of the EQ28 subscales with EC than PT are in line with previous findings (Dimitrijević et al., 2012). Moreover, the correlations of the EQ-28 subscales with measures of altruism and the Dark Triad show both theoretically expected and empirically documented relationships (Batson, 1991; Jonason \& Krause, 2013; Wai \& Tiliopoulos, 2012). In line with the empathy-altruism hypothesis, which states that empathy facilitates helping, our results confirmed a moderate relationship between the self-reported measure of altruism and the EQ-28. On the other hand, as one of the main characteristics of psychopathy is the lack of empathy, the obtained moderate negative relationship of the EQ-28 and psychopathy was also expected.

Lawrence et al. (2004) expressed concern about using a PCA on ordinal data obtained by the EQ, but stressed that, according to Hutcheson and Sofroniou (1999), this procedure is still useful as long as meaningful factors are extracted. Our study resulted in three easily and meaningfully interpretable factors comparable to all previously conducted EQ validation studies, therefore this shouldn't represent a threat to the results. The sample size and the misbalance in the gender ratio are one of the main limitations of this study; therefore a replication of the study with a more appropriate sample in Croatia is needed. Although our sample size was adequate for factor analysis, the factor structure would be more stable with a larger sample. 
Moreover, little is known whether there is gender invariance in factor structure of the EQ, as previous studies didn't examine it, and our subsample sizes weren't adequate for such analyses. Furthermore, we didn't have the ideal rates of internal consistency for all the scales in this research, especially for the short scales, so a replication with full scales is recommended. Nevertheless, the results of this preliminary study show that the Croatian version of the EQ-28 has satisfactory metric characteristics and represents a good measure of cognitive and emotional empathy, converging to research (e.g. Dimitrijević et al., 2012) that suggest shortening the EQ to only these two factors.

\section{REFERENCES}

Baron-Cohen, S. (2011). The science of evil: On empathy and the origins of cruelty. Philadelphia: Basic Books.

Baron-Cohen, S. \& Wheelwright, S. (2004). The Empathy Quotient: An investigation of adults with Asperger syndrome or high functioning autism, and normal sex differences. Journal of Autism and Developmental Disorders, 34(2), 163-175.

Batson, C. D. (1991). The altruism question: Toward a social psychological answer. Hillsdale, NJ: Erlbaum.

Berthoz, S., Wessa, M., Kedia, G., Wicker, B., \& Grezes, J. (2008). Cross-cultural validation of the empathy quotient in a French-speaking sample. Canadian Journal of Psychiatry, $53,469-477$.

Davis, M. H. (1983). Measuring individual differences in empathy: Evidence for a multidimensional approach. Journal of Personality and Social Psychology, 44, 113-126.

Dimitrijević, A., Hanak, N., Vukosavljević-Gvozden, T., \& Opačić, G. (2012). Psychometric properties of the Serbian version of the Empathy Quotient (S-EQ). Psihologija 45(3), 257-276.

Groen, Y., Fuermaier, A. B. M., Den Heijer, A. E., Tucha, O., \& Althaus, M. (2015). The Empathy and Systemizing Quotient: The Psychometric Properties of the Dutch Version and a Review of the Cross-Cultural Stability. Journal of Autism and Developmental Disorders, 1-17.

Hogan, R. (1969). Development of an empathy scale. Journal of Consulting and Clinical Psychology, 33, 307-316.

Hutcheson, G. \& Sofroniou, N. (1999). The Multivariate Social Scientist. Sage Publications Ltd: London.

Jonason, P. K. \& Krause, L. (2013). The emotional deficits associated with the Dark Triad traits: Cognitive empathy, affective empathy, and alexithymia. Personality and Individual Differences, 55, 532-537.

Jones, D. N. \& Figueredo, A. J. (2013). The core of darkness: Uncovering the heart of the Dark Triad. European Journal of Personality, 27, 521-531.

Jones, D. N. \& Paulhus, D. L. (2011). Differentiating the Dark Triad within the interpersonal circumplex. In L. M. Horowitz \& S. Strack (Eds.), Handbook of interpersonal 
psychology: Theory, research, assessment, and therapeutic interventions (pp. 249-268). New York: Wiley.

Jones, D. N. \& Paulhus, D. L. (2014). Introducing the Short Dark Triad (SD3): A brief measure of dark personalities. Journal of Research in Personality, 21, 28-41.

Kim, J. \& Lee, S. J. (2010). Reliability and validity of the Korean version of the Empathy Quotient Scale. Psychiatry Investigation, 7, 14-3.

Lawrence, E. J., Shaw, P., Baker, D., Baron-Cohen, S. \& David, A. S. (2004). Measuring Empathy - reliability and validity of the empathy quotient. Psychological Medicine, 34, 911-919.

Lee, K. \& Ashton, M. C. (2004). Psychometric properties of the HEXACO personality inventory. Multivariate Behavioral Research, 39, 329-358.

Lepage, J.-F., Lortie, M., Taschereau-Dumouchel, V., \& Theoret, H. (2009). Validation of French-Canadian versions of the Empathy Quotient and Autism Spectrum Quotient. Canadian Journal of Behavioral Science, 41, 272-276.

Mehrabian, A. \& Epstein, N. (1972). A measure of emotional empathy. Journal of Personality, 40, 525-543.

Muncer, S. J. \& Ling, J. (2006). Psychometric analysis of the empathy quotient (EQ) scale. Personality and Individual Differences, 40(6), 1111-1119.

Preti, A., Vellante, M., Baron-Cohen, S., Zucca, G., Petrello, D. R., \& Masala, L. (2011). The Empathy Quotient: A cross-cultural comparison of the Italian Version. Cognitive Neuropsychiatry, 16, 50-70.

Raboteg-Šarić, Z. (1995). Psihologija altruizma. (Psychology of Altruism). Zagreb: Alinea.

Shamay-Tsoory, S. G., Aharon-Peretz, J., \& Perry, D. (2009). Two systems for empathy: A double dissociation between emotional and cognitive empathy in inferior frontal gyrus versus ventromedial prefrontal lesions. Brain, 12, 617-627.

Singer, T. (2006). The neuronal basis and ontogeny of empathy and mind reading: Review of literature and implications for future research. Neuroscience \& Biobehavioral Reviews, 30, 855-863.

Wai, M. \& Tiliopoulos, N. (2012). The affective and cognitive empathic nature of the Dark Triad of personality. Personality and Individual Differences, 52, 794-799.

Wakabayashi, A., Baron-Cohen, S., Wheelwright, S., Goldenfeld, N., Delaney, J., Fine, D., Smith, R., \& Weil, L. (2006). Development of short forms of the Empathy Quotient (EQShort) and the Systemizing Quotient (SQ-Short). Personality and Individual Differences, 41, 929-940. 


\title{
FAKTORSKA STRUKTURA I PSIHOMETRIJSKE KARAKTERISTIKE HRVATSKE KRATKE VERZIJE UPITNIKA KVOCIJENTA EMPATIJE
}

\begin{abstract}
Sažetak
Kvocijent empatije (EQ, Emapthy Qoutient, Baron-Cohen i Wheelwright, 2004) mjeri empatiju kao sposobnost prepoznavanja i razumijevanja tuđih misli i osjećaja, te odgovarajućeg emocionalnog reagiranja na njih. Iako je upitnik napravljen kako bi bio osjetljiv na nedostatak empatije kao dijela psihopatologije, često se koristi i u drugim područjima psihologijskih istraživanja. Cilj ovog rada bio je ispitati faktorsku strukturu i psihometrijske karakteristike hrvatskog prijevoda kraće verzije upitnika Kvocijenta empatije (EQ-28) koja se pokazala psihometrijski boljom od izvorne verzije (Lawrence i sur., 2004). Podaci su prikupljeni on-line na prigodnom uzorku sudionika $(N=115 ; 81$ ženskog i 34 muškog spola) prosječne dobi 31,30 godina $(S D=7,49)$ u okviru većeg istraživanja. Rezultati faktorske analize upućuju na jasnu trofaktorsku strukturu sukladnu strukturi dobivenoj u prijašnjim istraživanjima (Dimitrijević i sur., 2012; Lawrence i sur., 2004). Cronbachovi alfa koeficijenti odražavaju visoku unutarnju pouzdanost subskala kognitivne empatije i emocionalne reaktivnosti, no ne i subskale socijalnih vještina. Korelacije subskala EQ-28 i odgovarajućih subskala Interpersonalnog indeksa reaktivnosti (Davis, 1983) pružaju informacije o konvergentnoj valjanosti subskala kognitivne empatije i emocionalne reaktivnosti, a korelacije s mjerama altruizma (mjerenog putem HEXACO-PI-R upitnika, Lee i Ashton, 2004) i Mračne trijade (Jones i Paulhus, 2014) pokazuju teorijski očekivane odnose pripadajućih konstrukata. Na temelju rezultata ovog preliminarnog istraživanja može se reći kako hrvatska verzija kratkog upitnika Kvocijenta empatije (EQ-28) ima zadovoljavajuće metrijske karakteristike te predstavlja dobru mjeru kognitivne i emocionalne empatije, no ovi rezultati bi trebali biti replicirani na većem i spolno ujednačenijem uzorku.
\end{abstract}

Ključne riječi: Kvocijent empatije, psihometrijske karakteristike, hrvatska verzija

Prihvaćeno za tisak: 07. 09. 2016. 